Madera y Bosques vol. 25, núm. 2, e2521715 Summer 2019 Scientific papers

\title{
Culture of Pleurotus ostreatus in pine shavings: isolation of strains and evaluation
} of their productivity

\section{Cultivo de Pleurotus ostreatus en viruta de pino: obtención de cepas y evaluación de su productividad}

\author{
Gerardo Mata', José Antonio Pérez-Torres², Rosario Medel², Rosalía Pérez-Merlo' and Dulce Salmones* \\ Instituto de Ecología, A. C. Red de Manejo \\ Biotecnológico de Recursos. Xalapa, Veracruz, \\ México. \\ 2 Universidad Veracruzana. Instituto de * Corresponding author. dulce.salmones@inecol.mx \\ Investigaciones Forestales. Xalapa, Veracruz \\ México.
}

\section{ABSTRACT}

In order to obtain strains of the edible mushroom Pleurotus ostreatus that can be cultivated in pine wood shavings, 36 monosporic cultures were isolated and propagated in vitro, selecting 6 cultures of rapid mycelial growth in order to obtain interspecimen crosses and dikaryonmonokaryon mating. Eleven of the crosses obtained and their 6 parental strains were cultured in vitro in order to determine their growth in pine shavings and barley straw (control), selecting 6 strains ( 3 crosses, 3 parental strains) for sporome production in the two growth substrates. At in vitro level, significant differences were found between the mycelial areas of monokaryons and dikaryons in the treatments (time, substrate) evaluated. In terms of sporome productivity, the cultures in barley straw presented higher biological efficiency (22.6\%$46.4 \%)$ and production rate $(0.31 \%-0.77 \%)$ values than those in the pine shavings $(3.3 \%-12 \%$ and $0.03 \%-0.11 \%$, respectively). Sporome pileus diameters of $5 \mathrm{~cm}$ to $9.9 \mathrm{~cm}$ were the most frequent in both substrates. In general, the crosses surpassed their parents in both mycelial growth and sporome production, although further study is required in order to facilitate increased productivity of the strains in this potentially useful agroforestry residue.

KEYWORDS: crosses, culture, edible fungi, Mexico, mushrooms, pine shavings

\section{RESUMEN}

Con el fin de obtener cepas del hongo comestible Pleurotus ostreatus con capacidad de cultivarse en viruta de pino, se aislaron y propagaron in vitro 36 cultivos monospóricos, seleccionándose 6 cultivos de rápido crecimiento micelial para obtener cruzas interespecimen y dicariónmonocarión. Once de las cruzas obtenidas más sus 6 parentales fueron cultivadas in vitro para determinar sus áreas miceliales en viruta de pino y paja de cebada (testigo), seleccionándose seis cepas ( 3 cruzas, 3 parentales) para producir sus esporomas en viruta de pino y paja de cebada (testigo). A nivel in vitro, se encontraron diferencias significativas entre las áreas miceliales de monocariones y dicariones en los tratamientos (tiempo, sustrato) evaluados. En cuanto a productividad de los esporomas, los cultivos en paja de cebada alcanzaron valores más altos de eficiencias biológicas (22.6\%-46.4\%) y tasas de producción $(0.31 \%-0.77 \%)$ que en que viruta de pino $(3.3 \%$ - $12 \%)$ y $(0.03 \%$ - $0.11 \%$ ), respectivamente. Los esporomas con diámetros de píleo de $5 \mathrm{~cm}$ a $9.9 \mathrm{~cm}$ de largo fueron más abundantes en ambos sustratos. En general, las cruzas superaron a sus parentales tanto en crecimiento micelial como en producción de esporomas, aunque se requiere más estudios que permitan incrementar la productividad de las cepas en este potencial residuo agroforestal.

PALABRAS CLAVE: cruzas, cultivo, hongos comestibles, México, setas, viruta de pino. 


\section{INTRODUCTION}

According to the Secretaría de Medio Ambiente y Recursos Naturales [Semarnat] (2016), forestry timber production in Mexico reached $6.1 \times 10^{6} \mathrm{~m}^{3}$ in the year 2015, accounting for $74.8 \%$ of the total production of the genus Pinus, the main conifer group used. This agroindustry generates wastes or byproducts wood (chips, cuttings or shavings) with suitable properties for bioenergy production, but the chemical composition of these materials is the main factor limiting their use (Wagner, Donaldson, \& Ralph, 2012).

Wood, as other lignocellulosic materials, is mainly constituted by cellulose, hemicellulose and lignin (Novaes et al., 2010), and it is the complexity of these macromolecules, as well as the close relationship that exists among them, that requires pretreatment in order to increase digestibility (Kumar, Barret, Delwiche, \& Stroeve, 2009).

The rate of microbial treatment is much lower than that for most other pretreatment methods and has been considered for many years a factor that prevents industrial use (Galbe \& Zacchi, 2012). However, in recent years, the environmentally-friendly approach of microbial pretreatment has received renewed attention and new studies have been performed involving fungi that degrade lignocellulose (Hatakka \& Hammel, 2010; Wan \& Li, 2012; Chatuverdi \& Verma, 2013) and improve the subsequent enzymatic hydrolysis.

Among the genera of edible white-rot fungi currently cultured at an industrial level, the species of the genus Pleurotus are prominent for their high efficiency in terms of degrading lignocellulose through the action of different hydrolytic and oxidative enzymes, the actions of which generate compounds of lower complexity which can then be used by the fungus for nutrition (Camassola, 2013; Mata, Savoie \& Salmones, 2017). Consequently, these fungi have the capacity to grow on practically any lignocellulosic material, under a wide range of environmental conditions, presenting a high production of fructifications compared to other edible mushrooms (Guzmán et al., 2013). Among the species of the genus currently cultured at industrial level, $P$. ostreatus is notable for this high biodegradative capacity (Lettera, Del Vecchio, Piscitelli, \& Sannia, 2011).

While species of Pleurotus are distinguished by their efficient capacity for lignocellulose degradation, the presence of extractive substances (resinic acids, fatty acids, tannins, hydrocarbons, phenols, among others) in pine wood residues has been a limiting factor in their use in this food agroindustry (Lomelí-Ramírez et al. 2009). For this reason, in the few reports of Pleurotus culture in pine residues that exist, the substrate has been previously biodegraded by other lignocellulotic species of fungi (Croan, 2004) and/or chemically pretreated (Croan 2000; Croan 2003) in order to increase the capacity for mycelial invasion and fructification development.

Programs of genetic improvement in commercially cultured species have focused mainly on increasing strain productivity (Mata, Gaitán-Hernández, \& Salmones, 2016). The use of mating-type genes has been very fruitful for such strain improvement and breeding strategies in Pleurotus (Gaitán-Hernández \& Salmones 2008; Gupta, Reddy, \& Kotasthane, 2011), mainly using gramineae straw as a substrate for productivity evaluation.

Pérez-Merlo \& Mata (2005) conducted genetic crossing of Pleurotus strains in order to identify germplasm with characteristics suitable for massive propagation in sterilized pine shavings. The results of that study were encouraging since the fructification of some strains under these culture conditions was achieved. However, substrate sterilization requires costly equipment, for which reason it is desirable to optimize the substrate treatment process. Pleurotus is commercially cultured in pasteurized substrate (Salmones, 2017; Sheng, 2017).

\section{OBJECTIVES}

The objective of this study was, therefore, to continue the program of genetic selection of $P$. ostreatus strains in pine shaving residues in order to identify germplasm of rapid in vitro growth and evaluate its productivity in this pasteurized forestry residue. 


\section{MATERIALS AND METHODS}

\section{Strains}

The following parental strains of $P$. ostreatus were used: IE238, IE-239, IE-240, IE-241, IE-659-IE-664, IE-667. These originated from genetic crosses between commercial and wild strains produced previously in the laboratory (Pérez-Merlo \& Mata, 2005; Gaitán-Hernández \& Salmones, 2008).

This study was developed in three stages; firstly, monosporic cultures were isolated from parental strains of $P$. ostreatus that were found to be highly productive in gramineae straw. These were then cultured on pine shavings, selecting the monosporics that presented the greatest in vitro growth in order to perform the interspecimen crosses. Likewise, the selected cultures were used to obtain di-mon type crosses, combining these with dikaryons that presented a capacity for producing sporomes in pine shavings (Pérez-Merlo \& Mata, 2005). The second stage consisted of evaluating the mycelial growth of the crosses and their parents in vitro, using pine shavings as a substrate, and the final stage of the study was an evaluation of the sporome production capacity of the crosses and parents that presented the greatest in vitro growth.

\section{Acquisition of strains for crossing of monosporic cultures using the Buller phenomenon (dikaryon- monokaryon combination)}

The monosporic cultures were obtained from spore print of the strains IE 238, IE 240 and IE 241. For spore germination, a small fragment $\left(\approx 1 \mathrm{~cm}^{2}\right)$ of filter paper containing spores was introduced into $100 \mathrm{~mL}$ of sterile distilled water and agitated to favor dispersion of these structures in the liquid. Using this technique, dilutions of $1 \times 10^{2}, 1 \times 10^{4}$ and $1 \times 10^{6}$ were obtained. Aliquots of $0.5 \mathrm{~mL}$ were then taken from each dilution and sown in Petri dishes with potato dextrose agar culture medium (PDA, Bioxon). The cultures were incubated at $25{ }^{\circ} \mathrm{C}$ until spore germination.
Between 20 and 30 spores germinated from each strain were isolated and placed independently in Petri dishes with PDA and incubated until the mycelium covered the total surface of each dish. The monosporic condition of the isolates was corroborated microscopically by the absence of fibulae. Twelve monosporic cultures of each strain were chosen at random in order to evaluate their mycelial growth in pine shavings. For this, $7 \mathrm{~mm}$ diameter fragments of mycelium from each of the isolates were placed in Petri dishes containing $10 \mathrm{~g}$ of autoclave sterilized pine shavings $\left(121^{\circ} \mathrm{C} / 60 \mathrm{~min}\right)$ that had been previously hydrated to $75 \%$ $\pm 5 \%$. Incubation was conducted at $25{ }^{\circ} \mathrm{C}$ and the developed mycelial area estimated at 10 days, 15 days and 18 days of incubation, adapting the methodology of Vázquez-Covarrubias, Montes-Belmont, Jiménez Pérez, \& Flores Moctezuma (2013), which consists of drawing and digitalizing the areas covered by the mycelia. The images were processed using the software Adobe Photoshop CS3 Extended (Fig. 1). The two monosporic cultures of each parental strain that presented the greatest mycelial areas in pine shavings were intercrossed, avoiding reciprocity and producing twelve combinations.

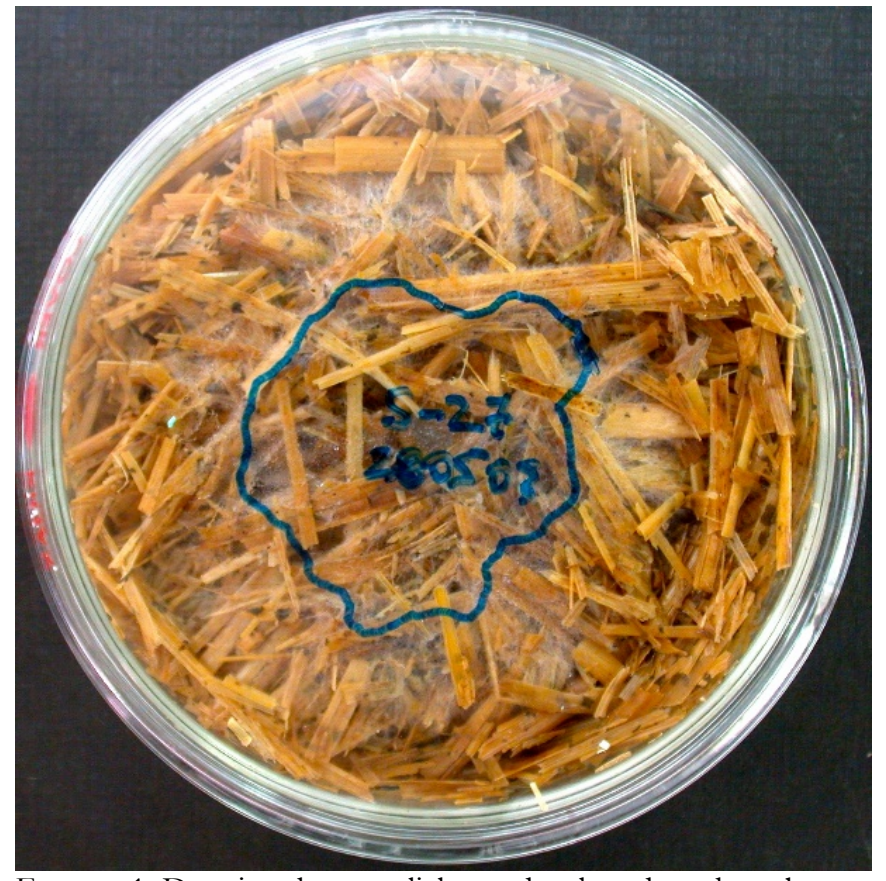

FIGURE 1. Drawing the mycelial area developed on the substrate, for its subsequent digitalization. 
For the second part of the genetic crossing, the interfecundation technique was used. In fungi, this is known as the Buller phenomenon and consists of obtaining new germplasm from the association of the nucleus of a monokaryon with one of the nuclei of a dikaryon (James, 2016). For this stage, the dikaryons IE-659, IE-664 and IE667 were used. These had been previously selected in the laboratory for their sporome production capacity in pine shavings (Pérez Merlo, \& Mata, 2005). The monokaryons were those obtained in the first part of this study. The dikaryotic condition of the combinations produced was corroborated microscopically by observation of the presence of the connective structures known as fibulae.

\section{In vitro selection of dikaryons in pine shavings}

The obtained crosses and their parents were inoculated into Petri dishes containing $10 \mathrm{~g}$ of sterile pine shavings that had been previously hydrated to $75 \% \pm 5 \%$. In parallel, samples were prepared with $7 \mathrm{~g}$ of hydrated barley straw, which was considered the control substrate. In total, 5 replicates were evaluated for each condition per strain. The samples were incubated at $25{ }^{\circ} \mathrm{C}$ and their mycelial areas recorded following the technique described in the first stage of the study. The cultures developed in barley straw were measured at 5 days, 7 days and 10 days of incubation, while those in pine shavings were measured at 5 days, 7 days, 10 days and 15 days of incubation.

The crosses that presented the greatest mycelial growth in pine shavings, and their parental strains, were cultured under suitable conditions in order to determine their productivity indices.

\section{Evaluation of strain productivity}

The inoculum was produced with sterile sorghum (Sorghum vulgare Pers.) seeds, following the methodology of Guzmán et al. (2013). Inoculation consisted of placing a fragment of mycelium of each of the strains on the sterile seeds. The inoculated samples were incubated at $25^{\circ} \mathrm{C}$ in darkness for 20 days and/or until the mycelium had completely invaded the sorghum seeds.
For sowing of these strains, the hydrated pine shavings and barley straw substrates were placed in a container of water for 24 hours and the excess water drained. The substrates were then subjected to a thermal steam treatment $\left(60{ }^{\circ} \mathrm{C}-65^{\circ} \mathrm{C}\right)$ for $6 \mathrm{~h}$. Samples were prepared in $40 \mathrm{~cm} \times$ $60 \mathrm{~cm}$ plastic bags containing $2 \mathrm{~kg}$ (moist weight) of each of the pasteurized substrates, which were inoculated at 5\% with the previously prepared seeds. A total of 7 replicates were produced per strain and substrate. The sown bags were incubated in a dark area at $25{ }^{\circ} \mathrm{C}$. One day after sowing, in order to facilitate respiration of the mycelium, 18 small perforations were made in each bag with sterile dissection needles.

Once the substrate was covered by the mycelium and the primordia had appeared, the samples were moved to the production area and maintained under conditions of illumination $(12 \mathrm{~h} /$ day $)$, temperature $\left(22{ }^{\circ} \mathrm{C} \pm 4{ }^{\circ} \mathrm{C}\right)$, relative humidity $(80 \%-85 \%)$ and ventilation, with fresh air introduced every 90 minutes for half an hour, in order to induce the appearance of sporomes.

The number of days required by each strain for primordia formation was recorded, as well as the number of harvests obtained and the fresh weight of the fruiting bodies. Productivity of the strains was expressed as biological efficiency (BE), i.e., the relationship between the fresh weight of the mushrooms produced and the dry weight of the substrate, expressed as a percentage. The rate of production (RP) was also quantified; this was the ratio between the $\mathrm{BE}$ and the number of days in one culture cycle, expressed as a percentage (Royse \& Chalupa, 2009). In addition, the harvested sporomes were classified into four size groups according to pileus diameter: $\mathrm{G} 1:<5 \mathrm{~cm}$; G2: $5 \mathrm{~cm}$ to $9.9 \mathrm{~cm}$; G3: $10 \mathrm{~cm}$ to $14.9 \mathrm{~cm}$, and $\mathrm{G} 4: \geq 15$ cm (Gaitán-Hernández et al., 2009).

\section{Experimental design}

For the values of the mycelial areas of the 12 monosporic mycelia of the strains IE-238, IE-240 and IE-241, a completely random experimental design was used, considering 12 treatments in quintuplicate and the mycelial 
diameters at 10 days, 15 days and 18 days of incubation as the response variable. For the in vitro mycelial area tests on barley straw and pine shavings, a totally random design was used with a factorial arrangement in which the effect of 17 strains (11 crosses and 6 parental) was tested on the two substrates, i.e., 34 treatments, each replicated five times, with the mycelial areas developed at 5 days, 7 days, 10 days and 15 days of incubation as the response variable. In all cases, the maximum growth time of the strains was considered to select them (monosporic, parental strains or crosses).

A completely random design with factorial arrangement was applied for the stage of sporome production in the greenhouse, evaluating 12 treatments (6 strains, 2 substrates), with the indices of $\mathrm{BE}$ and $\mathrm{RP}$ as responsible variables. These results were subjected to an analysis of variance of $95 \%$ confidence, with a Fisher means comparison test, in order to select the cultures that presented the greatest growth and sporome production in the pine wood substrate, using the package STATISTICA version 6.

\section{RESULTS}

\section{Isolation of strains by crossing of monosporic cultures using the Buller phenomenon (dikaryon- monokaryon combination)}

The spores germinated between 3-4 days of incubation and the monosporic cultures isolated required between 10-15 days to cover the total surface of the Petri dishes, coinciding in this regard with previously conducted studies using strains of Pleurotus (Gaitán-Hernández \& Salmones, 2008; Guadarrama-Mendoza et al., 2014).
The maximum and minimum values of the mycelial areas presented by the monosporics in pine shavings, as well as the corresponding ANOVA $(\mathrm{P}<0.001)$, are shown in table 1. Of the 36 monosporics evaluated, only one of the strain IE-241 did not present growth in this substrate. In general, and independently of incubation time, the parental strain IE-240 was distinguished by presenting less dispersed values that the other strains. At 18 days of incubation, the monosporics 11 and 12 of IE-238, 6 and 12 of IE-240 and 9 and 1 of IE-241 reached the highest values of mycelial growth, differing statistically in this regard from the rest of the evaluated mycelia (Tab. 2). The interspecimen combinations using these monosporics of rapid growth produced 12 crosses, of which only three combinations presented fibulae.

In terms of the di-mon crosses, with the combination of the monosporics originating from the strains IE-238, IE240 and IE-241 and the dikaryons IE-659, IE-664 and IE667 , eight more crosses were achieved. In total, 11 crosses were obtained for the two methods of genetic crossing used. In order to facilitate their citation, these crosses and their parents were assigned an alphabetic code of identification (Tab. 3).

\section{In vitro selection of dikaryons in pine shavings}

Different growth patterns were observed in the strains cultured in both substrates; however, the samples inoculated in the barley straw generally presented a more rapid growth than those developed in pine shavings, since the mycelia in the former completely covered the surface of the Petri dishes at 10 days of incubation, while in the latter, 15 days of incubation were required just for the mycelia to partially reach the side of the dishes.

TABLE 1. Maximum and minimum values of the mycelial areas developed by P. ostreatus monosporic cultures growing in pine shavings, at the different incubation times evaluated

\begin{tabular}{|c|c|c|c|c|c|}
\hline Strains & $\begin{array}{c}\text { Mycelial areas }\left(\mathrm{cm}^{2}\right) \\
\text { Days }\end{array}$ & & & & \\
\hline & 10 & 15 & 18 & $P>F$ & F calculada \\
\hline IE-238 & $3.6-12.5$ & $8.7-31.9$ & $17.3-50.5$ & 0.00000000000166 & 5.3050 \\
\hline IE-240 & $7.9-14.1$ & $18.5-26.9$ & $36.5-48.7$ & 0.0000002137 & 3.4478 \\
\hline IE-241 & $0-18.1$ & $0-43.1$ & $0-56$ & $<0.001$ & 10.294 \\
\hline
\end{tabular}


TABLE 2. Mycelial areas developed by the monosporics cultures on pine shavings at 18 days of incubation

\begin{tabular}{cccccc}
\hline & IE-238 & \multicolumn{2}{c}{$\mathrm{IE}-240$} & \multicolumn{2}{c}{$\mathrm{IE}-241$} \\
\hline No. & $\mathrm{cm}^{2}$ & No. & $\mathrm{cm}^{2}$ & No. & $\mathrm{cm}^{2}$ \\
\hline $11^{*}$ & $50.5 \mathrm{a}^{2}$ & $12^{*}$ & $48.7 \mathrm{a}$ & $9^{*}$ & $56.0 \mathrm{a}$ \\
$5^{*}$ & $42.3 \mathrm{ab}$ & $6^{*}$ & $46.7 \mathrm{ab}$ & $1^{*}$ & $49.8 \mathrm{~b}$ \\
2 & $41.5 \mathrm{abc}$ & 1 & $43.8 \mathrm{abc}$ & $5^{*}$ & $48.5 \mathrm{~b}$ \\
12 & $39.2 \mathrm{bcd}$ & 3 & $42.7 \mathrm{abc}$ & $3^{*}$ & $48.1 \mathrm{~b}$ \\
3 & $37.5 \mathrm{bcde}$ & 4 & $41.6 \mathrm{abc}$ & $6^{*}$ & $48.1 \mathrm{~b}$ \\
6 & $36.3 \mathrm{bcde}$ & 2 & $41.4 \mathrm{abc}$ & 11 & $46.6 \mathrm{bc}$ \\
9 & $31.7 \mathrm{cdef}$ & 9 & $40.6 \mathrm{abc}$ & 2 & $41.3 \mathrm{~cd}$ \\
8 & $31.1 \mathrm{def}$ & 11 & $39.7 \mathrm{abc}$ & 12 & $40.2 \mathrm{de}$ \\
7 & $31.0 \mathrm{def}$ & 7 & $38.8 \mathrm{bc}$ & 4 & $37.2 \mathrm{def}$ \\
1 & $28.6 \mathrm{ef}$ & 10 & $37.5 \mathrm{bc}$ & 10 & $34.5 \mathrm{ef}$ \\
10 & $25.1 \mathrm{fg}$ & 5 & $36.7 \mathrm{c}$ & 7 & $33.8 \mathrm{f}$ \\
4 & $17.3 \mathrm{~g}$ & 8 & $36.5 \mathrm{c}$ & 8 & $0 \mathrm{~g}$ \\
\hline
\end{tabular}

Monosporics selected in order to obtain the interspecimen crosses. ${ }^{2}$ Values with same letters are not statistically significant ( $p=0.05$, Fisher).

Due to the rapid growth of the strains in the barley straw (control substrate), the values reached at 5 days and 7 days of incubation had to be used for the comparative statistical analysis of growth of the strains (Fig. 2). Under these conditions, the analysis of variance in the mycelial growth values of the strains showed significant differences and the Fisher means comparison test $(p=0.05)$ revealed, for the factor substrate, that the barley straw presented greater mycelial growth that the pine shavings. For the factor strain, the interspecimen crosses $\mathrm{I}$ and $\mathrm{H}$ presented the highest values, surpassing those of their respective parental strains and the other progeny strains evaluated. The remaining interspecimen cross $(\mathrm{G})$ presented statistically similar values to those of its parental strains. The di-mon crosses presented similar or lower values to those of their progenitor strains.

Regarding the mycelial growth of the strains on pine shavings, the interspecimen crosses $\mathrm{H}$ and I developed the greatest mycelial areas at 5 days and 7 days of incubation, differing statistically in this regard from the rest of the evaluated strains.

In terms of the parental strains, $A, B$ and $C$ presented greater growth than $\mathrm{D}, \mathrm{E}$ and $\mathrm{F}$, under all the studied conditions. In terms of the effect of the interaction between strain and substrate, the Fisher means comparison analysis showed that, over time, the mycelial growth of the strains in barley straw surpassed that obtained in pine shavings, regardless of the strain used.

The mycelial areas developed in pine shavings at 10 and 15 days of incubation are presented in figure 3 . The values ranged from $5 \mathrm{~cm}^{2}$ (cross L) to $22.7 \mathrm{~cm}^{2}$ (cross I) at 10 days of incubation; and from $21.2 \mathrm{~cm}^{2}$ (parental D) to $41.7 \mathrm{~cm}^{2}$ (parental C) $\mathrm{cm}^{2}$ at 15 days of incubation. The parental strains $\mathrm{A}, \mathrm{C}$ and $\mathrm{F}$ and the crosses $\mathrm{I}, \mathrm{N}$ and $\mathrm{O}$ produced the highest values of mycelial growth in the pine shavings substrate, presenting no significant differences among themselves, but differing from the rest of the studied strains. For this reason, these 6 strains were selected for evaluation of sporome production capacity.

TABLE 3. Code assigned and origin of P. ostreatus strains selected in the laboratory

\begin{tabular}{ccclll}
\hline Code & Parental & Code & Interspecimen crosses & Code & Di-mon crosses \\
\hline A & IE-238 & G & IE-238 (12) x IE-240 (12) & J & IE-238 (12) x IE-659 \\
B & IE-240 & H & IE-238 (11) x IE-241 (1) & K & IE-238 (11) x IE-664 \\
C & IE-241 & I & IE-238 (11) x IE-241 (9) & L & IE-238 (12) x IE-664 \\
D & IE-659 & & & M & IE-240 (12) x IE-664 \\
E & IE-664 & & N & IE-241 (9) x IE-664 \\
$F$ & IE-667 & & O & IE-238 (11) x IE-667 \\
& & & P & IE-240 (12) x IE-667 \\
& & & Q & IE-241(1) x IE-667
\end{tabular}



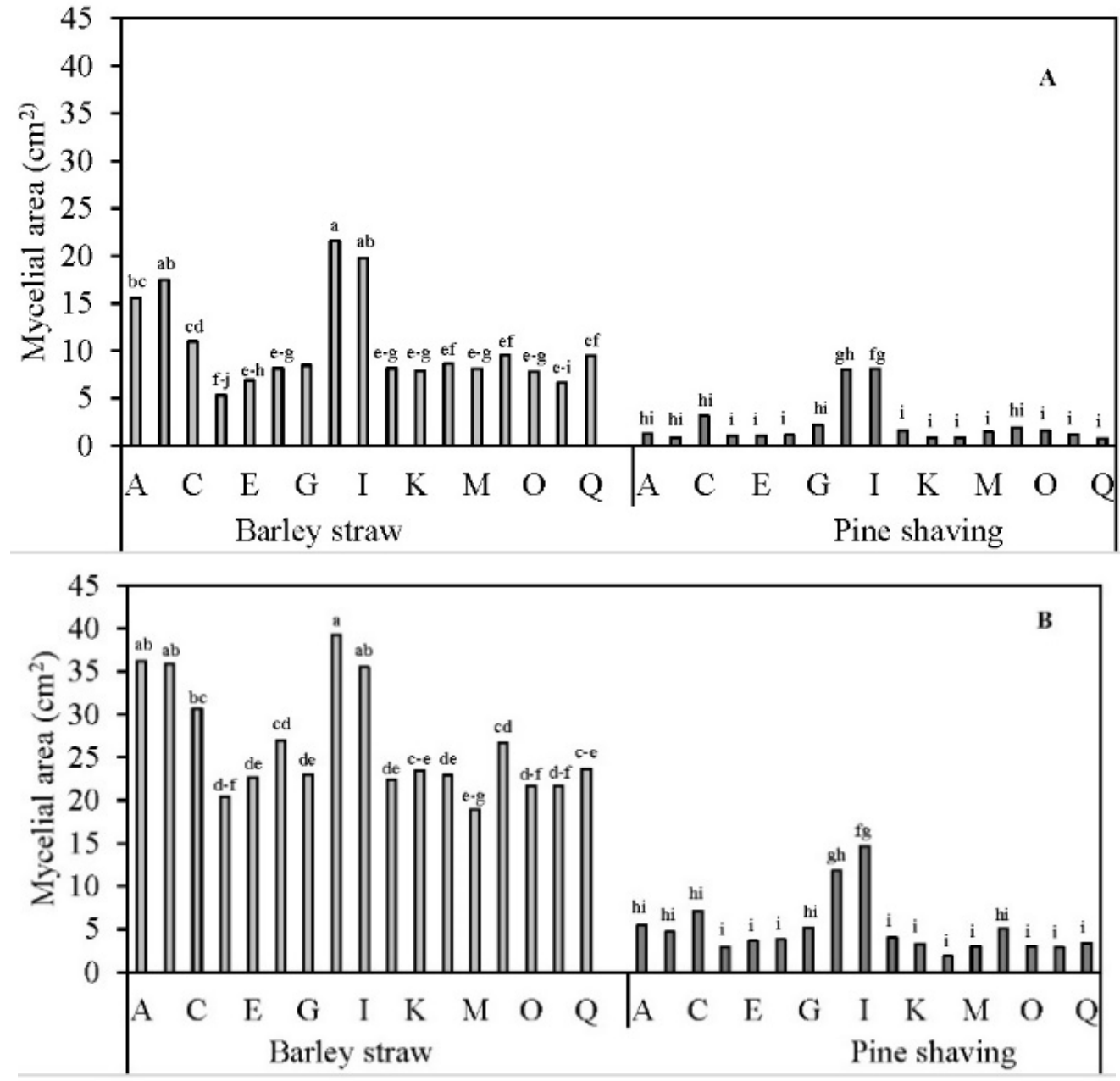

FIGURE 2. Effect of the strain-substrate interaction on the mycelial growth of the P. ostreatus strains evaluated at 5 (A) and 7 (B) days of incubation. By each substrate and incubation time, bars with same letters are not statistically significant $(p=0.05$, Fisher).

\section{Evaluation of strain productivity}

In this stage, the mycelium of each of the 6 strains evaluated required between 15 days and 20 days of incubation to completely cover the grains of sorghum used to prepare the inoculum, with earlier invasion of the substrate observed in the parental strains compared to the crosses evaluated. In terms of incubation period, the samples required 35 days to completely cover the pine shavings but only 25 days in the barley straw.

Interspecimen cross I was distinguished by the early development of its reproductive structures, since primordia were presented in the barley straw from day 30 of incubation and the first sporomes were harvested at 34 days of incubation. In the pine shavings, however, the primordia were observed from day 55 of incubation and the first harvest was produced at 60 days. On average, from 1 to 2 harvests were evaluated in cultured cycles that ranged from 60 to 76 days in barley straw and from 85 days to 106 days in pine shavings. Two of the parental strains (A and C) did not develop sporomes in the pine substrate (Table 4).

Statistical analysis of the productivity values showed significant differences between the $\mathrm{BE}$ and $\mathrm{RP}$ of the strains cultured in the different substrates $(p<0.05)$. In pine shavings, the productivities of the parental $\mathrm{F}$ and the cross O surpassed those of the rest of the strains, reaching BE values of $11.6 \%$ and $12 \%$, with RP values of $0.11 \%$. In terms of the samples in barley straw, cross I and parental strain C presented the highest BE (46.4\% and 44.6\%, respectively) and $\mathrm{RP}(0.77 \%$ and $0.59 \%$, respectively) values (Table 4). 

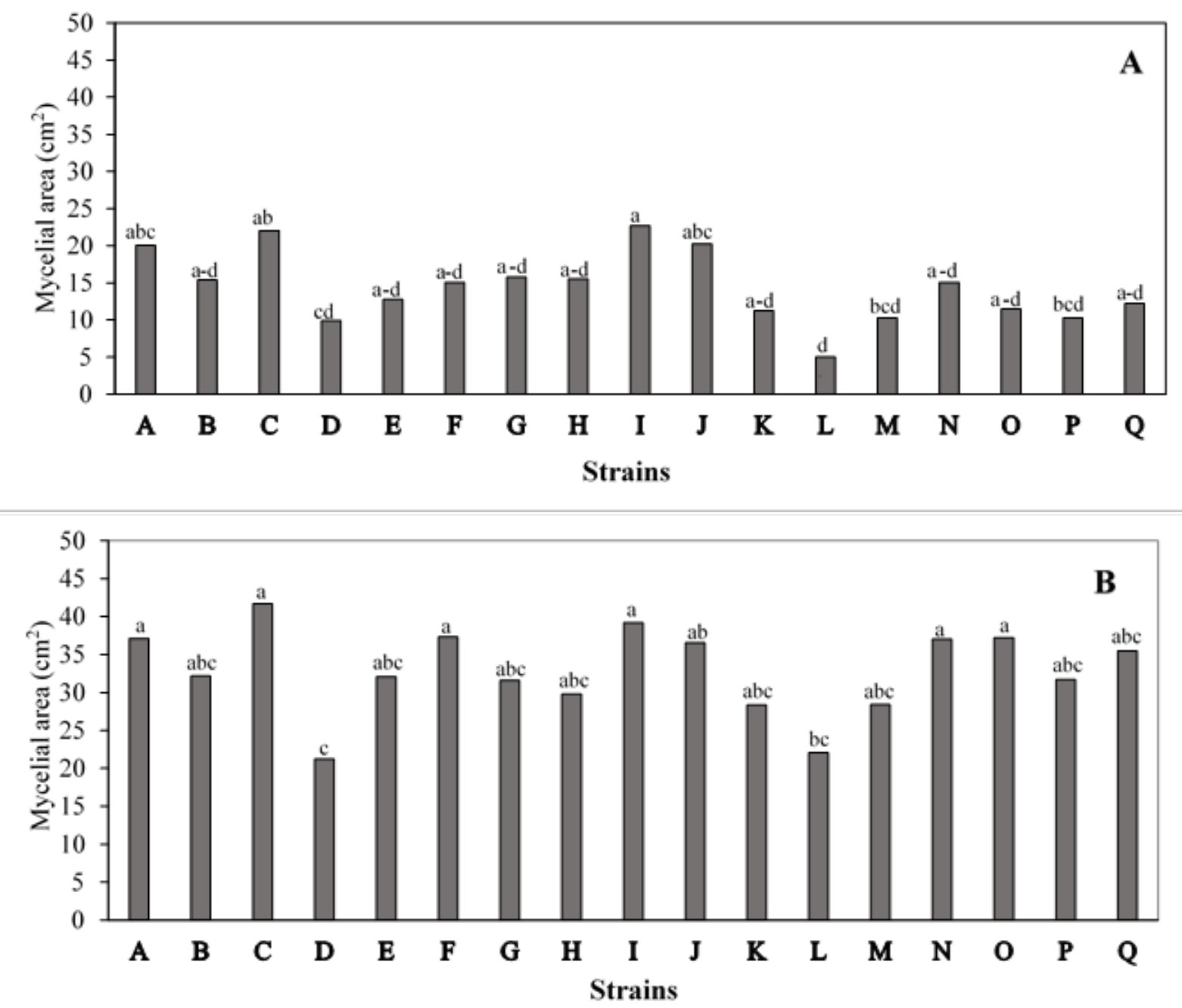

FIGURE 3. Mycelial areas of $P$. ostreatus strains developed in pine shavings at 10 days (A) and 15 days (B) of incubation. By each incubation time, bars with same letters are not statistically significant $(p=0.05$, Tukey).

TABLE 4. Productivity of $P$. ostreatus strains cultivated on substrates

\begin{tabular}{lllllllll}
\hline \multirow{2}{*}{ Strains } & \multicolumn{7}{l}{ Barley straw } & Pine shaving \\
\cline { 2 - 8 } & PI & 1stF & BE & PR & PI & $1 s t F$ & EB & PR \\
\hline A & $45^{1}$ & 49 & $25.6 c^{2}$ & $0.34 c$ & - & - & - & - \\
C & 46 & 50 & $44.6 \mathrm{ab}$ & $0.59 \mathrm{ab}$ & - & - & - & - \\
$\mathrm{F}$ & 39 & 43 & $33.6 \mathrm{abc}$ & $0.49 \mathrm{bc}$ & 67 & 70 & $11.6 \mathrm{a}$ & $0.11 \mathrm{a}$ \\
$\mathrm{I}$ & 30 & 34 & $46.4 \mathrm{a}$ & $0.77 \mathrm{a}$ & 55 & 60 & $6.4 \mathrm{~b}$ & $0.07 \mathrm{~b}$ \\
$\mathrm{~N}$ & 43 & 49 & $22.6 \mathrm{c}$ & $0.31 \mathrm{c}$ & 76 & 83 & $3.3 \mathrm{c}$ & $0.03 \mathrm{c}$ \\
$\mathrm{O}$ & 44 & 50 & $29.4 \mathrm{bc}$ & $0.40 \mathrm{bc}$ & 69 & 72 & $12 \mathrm{a}$ & $0.11 \mathrm{a}$ \\
\hline
\end{tabular}

PI: Primordia initiation (days), IstF: First flush (days), BE: Biological efficiency (\%), PR: Production rate (\%).

Values are average of six replicates. ${ }^{2}$ Columns with the same letters are not statistically significant $(p=0.05$, Fisher). 
Regarding the pileus size classification of the sporomes, in the samples cultivated in barley straw, the parentals A, C and $\mathrm{F}$ developed mushrooms of groups 1 to 3 , with the harvest of basidiomes of group 1 predominating in strains $A$ and $C$ and those of group 2 in strain F. Strain I was distinguished by the development of basidiomes greater than $15 \mathrm{~cm}$ (group 4), while strain $\mathrm{N}$ only presented basidiomes of group 1 and 2 (up to $10 \mathrm{~cm}$ in pileus diameter). In general, group 2 was predominant in the samples cultured in this substrate (Fig. 4).

In terms of the samples cultured in pine shavings, the dikaryons F, I and O developed sporomes of groups 1 and 2 , while strain $\mathrm{N}$ only presented fructifications of les than 5 $\mathrm{cm}$ in pileus diameter $(\mathrm{G} 1)$. As with that observed in the barley straw cultures, basidiomes of group 2 dominated the harvests in the pine shavings substrate (Fig. 4).

\section{DISCUSSION}

Studies conducted with the genus Pleurotus to determine in vitro mycelial growth using pine wood are very scarce, when compared to other substrates such as barley and wheat straw and even to other wood types. For this reason, the conditions of growth mycelial are little known and very variable (Sánchez \& Royse, 2001; Guzmán et al., 2013). One of the main problems in using the wood of conifers for mushroom cultivation is its capacity to synthesize two types of resins, preformed and induced, which act as a defense mechanism against insects and fungi and require a considerable length of time and high temperatures for their degradation (Bohlmann, 2012).

The germination times of the spores and in vitro growth of $P$. ostreatus in culture medium observed in the present study were similar to that previously reported for this species by Gaitán-Hernández \& Salmones (2008), as well as those of in vitro cultures on pine shavings (Pérez-Merlo \& Mata, 2005) and barley straw (Gupta, Reddy, \& Kotasthane, 2011). The differences observed in the mycelial growth between substrates was probably due to the chemical composition of the pine shavings (Hatakka \& Hammel, 2010). On the other hand, the genetic variability that exists among the germinated spores is chosen at random, based on the hypothesis that individuals that germinate early have a greater capacity for survival; however, the growth, development and reproduction of a fungal culture depends on many factors: genetic, physiological, biochemical and even environmental.

Pine wood has been little used as a substrate for the culture of Pleurotus, (Varnero, Quiroz \& Álvarez, 2010; Piškur et al., 2011). In pine shavings treated at $121^{\circ} \mathrm{C}$ for 90 min, Pérez-Merlo \& Mata (2005) reported the appearance of primordia at between 18 days and 25 days of incubation at a temperature of $25^{\circ} \mathrm{C}-28^{\circ} \mathrm{C}$. Croan (2000) states that when Pleurotus strains are cultivated in a substrate of American aspen (Populus tremuloides Michx), sterilized and with a glucose concentration adjusted to $1.5 \%$, primordia were produced between 3-5 weeks of incubation. In the present study, the pine wood shaving samples were pasteurized $\left(65^{\circ} \mathrm{C}\right)$ and no supplement was applied, and the formation of primordia observed from 55 days of incubation. With these results, it is evident that thermal treatment inflluences the growth response of the fungus on the pine shavings. It is important to highlight that sterilization is conducted in order to completely eliminate organisms that compete with Pleurotus spp. and are found in the lignocellulosic material; however, the process also causes structural and biochemical changes in the substrate that can positively or negatively affect mycelial growth (Sánchez, Andrade, \& Moreno, 2017), as was observed in the first stage of the present study. The pasteurization treatment of the substrate has the objective of limiting the number of competing organisms, such that competition for nutrients and space is reduced and growth and adaptation of the fungus favored. From an economic perspective, pasteurization can reduce operational costs, since costly specialized equipment is required for sterilization (Sheng, 2017). 


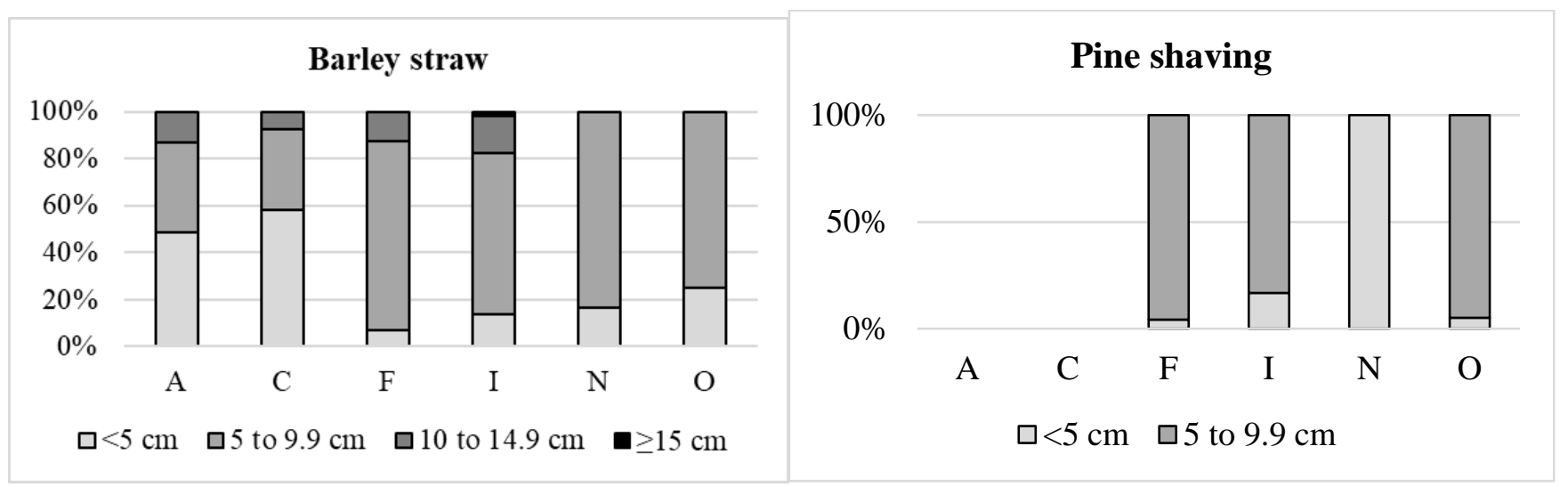

FIGURE 4. Percentage of fruiting bodies obtained from P. ostreatus strains cultivated on different substrates, grouped by pileus diameters.

The temperatures used in the thermal process play a very important role in nutrient availability (Brito, Silva, Leão, \& Almeida, 2008). It is known that temperatures below $55^{\circ} \mathrm{C}$ are insufficient to destroy organisms that are antagonistic to Pleurotus, while temperatures above $85{ }^{\circ} \mathrm{C}$ cause the partial rupture of the hydrogen bonds of the complex lignocellulose molecule, contributing to the solubilization of simple sugars, compounds easily assimilated not only by Pleurotus, but also by the majority of contaminant fungi, for which reason thermically processing the substrate at high temperatures can favor the greater presence of these antagonistic groups (Jaramillo \& Albertó, 2013; Sánchez, Andrade, \& Moreno, 2017).

Comparing the productivity results of the present study with those of previous reports (Pérez-Merlo \& Mata, 2005), it can be seen that the sterilization process in the pine shavings increased the availability of nutrients during the first days of incubation, favoring rapid colonization of the substrate and early fructification of the fungus, which presented a greater number of sporomes, albeit of small size (G1); in the case of the pasteurized pine shavings, the fungus may require a greater metabolic effort to detoxify the substrate and begin to degrade the components of the wood, for which reason the periods of incubation and primordia formation are extended, producing lower productivity but with the development of larger sporomes. In studies conducted previously by Croan (2003, 2004), fructifications of Pleurotus spp. only developed after removal of most of the extractives of the wood resins using the degrading fungi Ophiostoma piliferum. While the productivity results obtained in the present study are poorer than the values reported by Pérez-Merlo \& Mata (2005), they are similar to those reported by Gaitán-Hernández (2000), who cultured the edible species Neolentinus suffrutescens in pine wood (Pinus spp. and P. montezumae) and reported incubation periods of 37-54 days.

In terms of biological efficiencies and production rates in the wood of conifers, our results more closely reflect the estimates of Gaitán-Hernández (2000) with BE values of $4.41 \%-14.92 \%$ and RP values of $0.23 \%-0.6 \%$. PérezMerlo \& Mata (2005) found BE values of up to $53.53 \%$ and $\mathrm{RP}$ values of $0.63 \%-1.12 \%$, while $\mathrm{BE}$ values of 159 up to $500 \%$ have been obtained in other studies (Croan, 2000; 2003).

In general, the mycelial area of both monokaryons and dikaryons was unrelated to the productivity of the strains, apart from the interspecimen cross $\mathrm{O}$, which presented one of the highest mycelial areas at 15 days of in vitro incubation in pine wood and also presented among the highest BE and $\mathrm{RP}$ values. This seems to indicate that resistance of the strain to the toxic components of the substrate represents an important advantage during sporome formation.

\section{CONCLUSIONS}

In conclusion, softwood residues are potentially recommendable substrates for the culture of edible fungi; however, these materials present toxic and antiphysiological compounds that could affect the vegetative and 
reproductive development of the mushroom. The advances made to date in the isolation and selection of strains of $P$. ostreatus in pine wood shavings are promising but not yet economically viable, since the productivities of these strains are low and presented in long culture cycles. For this reason, further study is required in order to determine the effects of the antiphysiological compounds of the wood on the induction and development of the sporomes. This would contribute to increasing the productivity of the strains selected in vitro as well as developing protocols of substrate treatment to reduce the concentration of these antiphysiological compounds.

\section{ACKNOWLEDGEMENTS}

The authors thank the Institute of Ecology and Universidad Veracruzana for financial support. Thanks are also due to Biol. Carlos Ortega from Institute of Ecology for his support during experimental studies. José Antonio PérezTorres thanks Conacyt for the grant to study his master's degree in Ecology at the Universidad Veracruzana.

\section{REFERENCES}

Bohlmann, J., (2012). Pine terpenoid defences in the mountain pine beetle epidemic and in other conifer pest interactions: Specialized enemies are eating holes into a diverse, dynamic and durable defence system. Tree Physiology, 32(8), 943-945. doi: $10.1093 /$ treephys/tps065

Brito, J. O., Silva, F. G., Leão, M. M., \& Almeida, G. (2008). Chemical composition changes in eucalyptus and pinus woods submitted to heat treatment. Bioresource Technology, 99(18), 8545-8548. doi: 10.1016/j.biortech.2008.03.069

Camassola, M., da Rosa, L. O., Calloni, R., Gaio, T. A. \& Dillon, A. J. P. (2013). Secretion of laccase and manganese peroxidase by Pleurotus strains cultivate in solid-state using Pinus spp. sawdust. Brazilian Journal of Microbiology, 44(1), 207-213. doi: 10.1590/S1517-83822013005000006

Chaturvedi, V. \& Verma, P. (2013). An overview of key pretreatment processes employed for bioconversion of lignocellulosic biomass into biofuels and value-added products. 3 Biotech, 3(5), 415-431. doi: 10.1007/s13205-0130167-8

Croan, S. C. (2000). Conversion of wood waste into value-added products by edible and medicinal Pleurotus (Fr.) P. Karst.
Species (Agaricales s.l., Basidiomycetes). International Journal of Medicinal Mushrooms, 2, 73-80. doi: 10.1615/IntJMedMushr.v2.i1.80

Croan, S. C. (2003). Utilization of treated conifer wood chips by Pleurotus (Fr.) P. Karst. species for cultivating mushrooms. Mushrooms International, 91, 4-7.

Croan, S. C. (2004). Conversion of conifer wastes into edible and medicinal mushrooms Forest Products Journal, 54(2), 68-76.

Esteves, B. \& Pereira, H. (2009). Wood modification by heat treatment: a review. BioResources, 4, 370-404.

Gaitán-Hernández, R. (2000). Obtención de cepas de Neolentinus suffrutescens por entrecruzamiento, su caracterización in vitro y producción de cuerpos fructíferos a nivel planta piloto. Revista Iberoamericana de Micología, 17, 20-24.

Gaitán-Hernández, R. \& Salmones, D. (2008). Obtaining and characterizing Pleurotus ostreatus strains for commercial cultivation under warm environmental conditions. Scientia Horticulturae, 118(2), 106-110. doi:10.1016/j.scienta.2008.05.029

Gaitán-Hernández, R., Salmones, D., Pérez-Merlo, R., \& Mata, G. (2009). Evaluación de la eficiencia biológica de cepas de Pleurotus pulmonarius en paja de cebada fermentada. Revista Mexicana de Micología, 30, 63-71.

Galbe, M. \& Zacchi, G. (2012). Pretreatment: the key to efficient utilization of lignocellulosic materials. Biomass and Bioenergy, 46, 70-78. doi: 10.1016/j.biombioe.2012.03.026

Guadarrama-Mendoza, P.C., Valencia del Toro, G., RamírezCarrillo, R., Robles-Martínez, F., Yáñez-Fernández, J. Garín-Aguilar, M. E., Hernández, C. G., \& Bravo-Villa, G. (2014). Morphology and mycelial growth rate of Pleurotus spp. strains from the Mexican mixtec region. Brazilian Journal of Microbiology, 45(3), 861-872. doi: 10.1590/S151783822014000300016

Gupta, B., Reddy, B. N., \& Kotasthane, A. S. (2011). Molecular characterization and mating type analysis of oyster mushroom (Pleurotus spp.) using single basidiospores for strain improvement. World Journal of Microbiology and Biotechnology, 27(1), 1-9. doi: 10.1007/s11274-010-0419-2

Guzmán, G., Mata, G., Salmones, D., Soto-Velazco, C. \& Guzmán-Dávalos, L. (2013). El cultivo de hongos comestibles con especial atención a especies tropicales y subtropicales en esquilmos y residuos agroindustriales ( $3^{\mathrm{a}}$. Reimpresión). México, D. F.: Instituto Politécnico Nacional.

Hatakka, A. \& Hammel, K. E. (2010). Fungal biodegradation of lignocelluloses. In M. Hofrichter (Ed.), The Mycota: Industrial Applications $X$ (pp. 319-340). Berlin: Springer. doi: 10.1007/978-3-642-11458-8_15 
James, T. Y (2015). Why mushrooms have evolved to be so promiscuous: insights from evolutionary and ecological patterns: review. Fungal Biology Reviews, 29(3-4), 167-178. doi: 10.1016/j.fbr.2015.10.002

Jaramillo, S. \& Albertó, E. (2013). Heat treatment of wheat straw by immersion in hot water decreases mushroom yield in Pleurotus ostreatus. Revista Iberoamericana de Micología, 30(2), 125-129. doi: 10.1016/j.riam.2012.11.004.

Kumar, P., Barret, D. M., Delwiche, M. J., \& Stroeve, P. (2009). Methods for pretreatment of lignocellulosic biomass for efficient hydrolysis and biofuel production. Industrial Engineering Chemical Research, 48, 3713-3729. doi: 10.1021/ie801542g

Lettera, V., Del Vecchio, C., Piscitelli, A. \& Sannia, G. (2011). Low impact strategies to improve ligninolytic enzyme production in filamentous fungi: the case of laccase in Pleurotus ostreatus. Comptes Rendus Biologies, 334(11), 781788. doi: 10.1016/j.crvi.2011.06.001

Lomelí-Ramírez, M. G., Ochoa-Ruiz, H. G., Fuentes-Talavera, F. J., García-Enríquez, S., Cerpa-Gallegos, M. A. \& SilvaGuzmán, J. A. (2009). Evaluation of accelerated decay of wood plastic composites by Xylophagus fungi. International Biodeterioration and Biodegradation, 63(8), 1030-1035. doi: 10.1016/j.ibiod.2009.08.002

Mata, G., Gaitán Hernández, R., \& Salmones, D. (2016). La investigación en micología básica y aplicada: aportes para un desarrollo sustentable. In D. Martínez-Carrera \& J. RamírezJuárez (eds.), Ciencia, tecnología e innovación en el sistema agroalimentario de México (pp. 695-719). Texcoco: Colegio de Postgraduados-AMC-CONACyT-UPAEP-IMINAP.

Mata, G., Salmones, D., \& Savoie, J. M. (2017). Las enzimas lignocelulolíticas de Pleurotus spp. In J. E. Sánchez \& D. J. Royse (Eds.), La biología, el cultivo y las propiedades nutricionales y medicinales de las setas Pleurotus spp. (pp. 63-82). Tapachula: Ecosur.

Novaes, E., Kirst, M., Chiang, V., Winter-Sederoff, H., \& Sederoff, R. (2010). Lignin and biomass: A negative correlation for wood formation and lignin content in trees. Plant Physiology, 154, 555-561. doi: 10.1104/pp.110.161281

Pérez-Merlo, R. \& Mata, G. (2005). Cultivo y selección de cepas de Pleurotus ostreatus y P. pulmonarius en viruta de pino: obtención de nuevas cepas y evaluación de su producción. Revista Mexicana de Micología, 20, 53-59.

Piškur, B., Bajc, M., Robek, R., Humar, H., Sinjur, I., Kadunc, A., Oven, P., Rep, G., Petkovšek, S. A. S., Kraigher, H., Jurc, D., \& Pohleven, F. (2011). Influence of Pleurotus ostreatus inoculation on wood degradation and fungal colonization.
Bioresource Technology, 102(22), 10611-10617. doi: 10.1016/j.biortech.2011.09.008

Royse, D. J. \& Chalupa, W. (2009). Effects of spawn, supplement and phase II compost additions and time of re-casing second break compost on mushroom (Agaricus bisporus) yield and biological efficiency. Bioresource Technology, 100(21), 5277582. doi: 10.1016/j.biortech.2009.02.074

Salmones, D. (2017). Pleurotus djamor, un hongo con potencial aplicación biotecnológica para el neotrópico. Scientia Fungorum, 46, 73-85.

Sánchez, J. E., Andrade, R.H., \& Moreno, L. (2017). La protección del sustrato para el cultivo de Pleurotus spp. y otros hongos comestibles. In J. E. Sánchez \& D. J. Royse (Eds.), La biología, el cultivo y las propiedades nutricionales y medicinales de las setas Pleurotus spp. (pp. 107-126). Tapachula: Ecosur.

Sheng, Q. (2017). Producción commercial de la seta Pleurotus spp. In J. E. Sánchez \& D. J. Royse (Eds.), La biología, el cultivo y las propiedades nutricionales y medicinales de las setas Pleurotus spp. (pp. 127-148). Tapachula: Ecosur

Varnero, M. T., Quiroz, M. S., \& Álvarez, C. H. (2010). Utilización de residuos forestales lignocelulósicos para producción del hongo ostra (Pleurotus ostreatus). Información Tecnológica, 21(2), 13-20.

Vázquez-Covarrubias, D., Montes-Belmont, R., Jiménez Pérez, A. \& Flores Moctezuma, H. E. (2013). Aceites esenciales y extractos acuosos para el manejo in vitro de Fusarium oxysporum f. sp. bycopersici y F. solani. Revista Mexicana de Fitopatología, 31(2), 170-179.

Secretaría de Medio Ambiente y Recursos Naturales [Semarnat] (2016). Anuario Estadístico de la Producción Forestal 2015. México, D. F.: Secretaría de Medio Ambiente y Recursos Naturales.

Wagner, A., Donaldson, L., \& Ralph, J. (2012). Lignification and lignin manipulations in conifers. In L. Jouanin \& C. Lapierre (Eds.), Advances in botanical research, vol. 61, Lignins: Biosynthesis, biodegradation and bioengineering (pp. 37-76). Burlington: Academic Press, Burlington.

Wan, C. \& Li, Y. (2012). Fungal pretreatment of lignocellulosic biomass. Biotechnological Advances, 30(6), 1447-1457. doi: 10.1016/j.biotechadv.2012.03.003

Received: 12 February 2018

Accepted: 12 November 2018

Published: 19 August 2019 
This paper must be cited as:

Mata, G., Pérez-Torres, J. A., Medel, R., Pérez-Merlo, R. \& Salmones, D. (2019). Culture of Pleurotus ostreatus in pine shavings: isolation of strains and evaluation of their productivity. Madera y Bosques, 25(2), e2521715. doi: 10.21829/myb.2019.2521715
Madera y Bosques by Instituto de Ecología, A.C. is distributed under a Creative Commons License Attribution-NonCommercialShareAlike 4.0 International. 